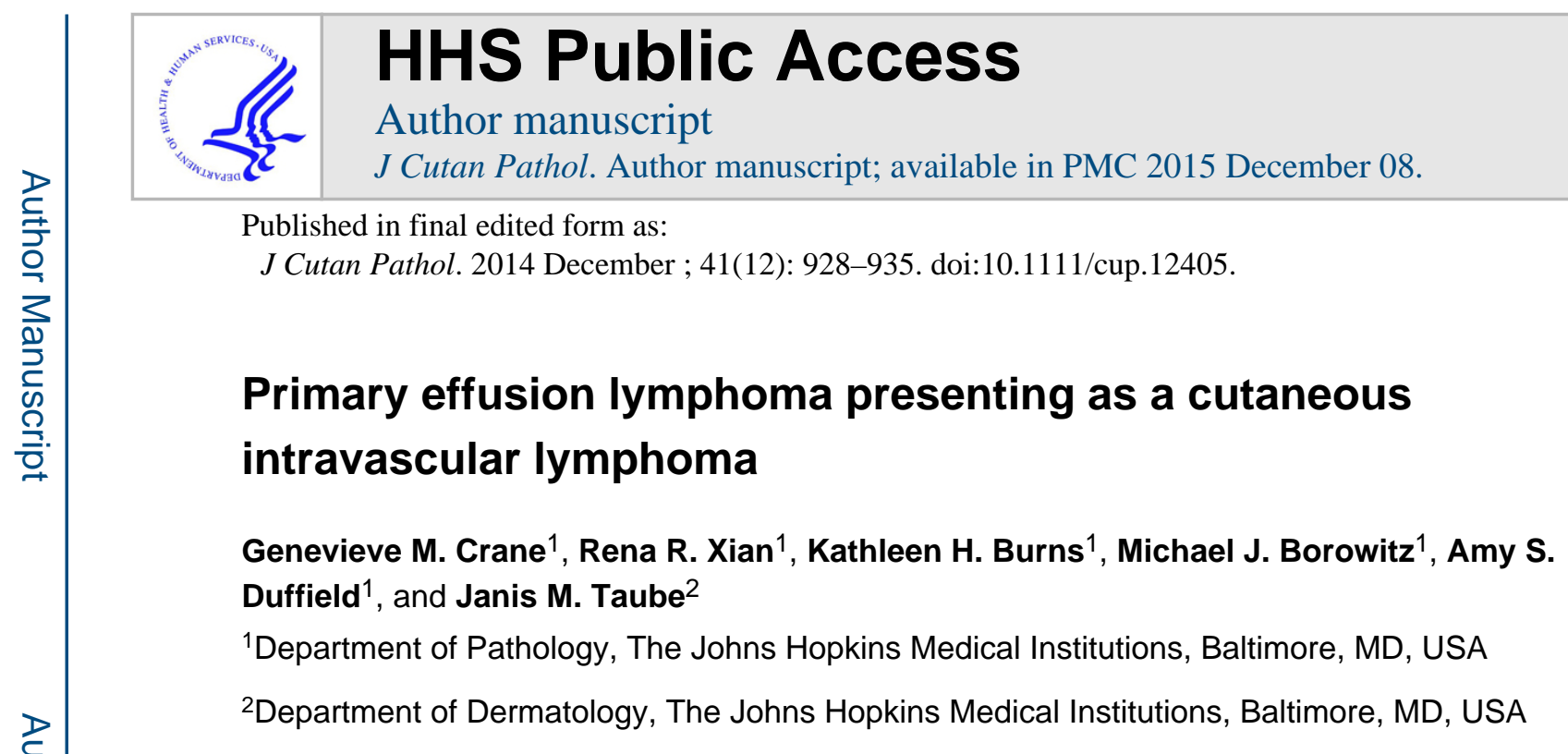

\begin{abstract}
Primary effusion lymphoma (PEL) is a rare and aggressive lymphoma that arises in the context of immunosuppression and is characterized by co-infection with Epstein-Barr virus (EBV) and human herpesvirus-8/Kaposi sarcoma-associated herpesvirus (HHV-8/KSHV). It was originally described as arising in body cavity effusions, but presentation as a mass lesion (extracavitary PEL) is now recognized. Here, we describe a case of PEL with an initial presentation as an intravascular lymphoma with associated skin lesions. The patient was a 53-year-old man with human immunodeficiency virus (HIV)/acquired immune deficiency syndrome (AIDS) who presented with fevers, weight loss and skin lesions concerning for Kaposi sarcoma (KS). A skin biopsy revealed no evidence of $\mathrm{KS}$; however, dermal vessels contained large atypical cells that expressed CD31 and plasma cell markers but lacked most B- and T-cell antigens. The atypical cells expressed EBV and HHV-8. The patient subsequently developed a malignant pleural effusion containing the same neoplastic cell population. The findings in this case highlight the potential for unusual intravascular presentations of PEL in the skin as well as the importance of pursuing microscopic diagnosis of skin lesions in immunosuppressed patients.
\end{abstract}

\title{
Keywords
}

Epstein-Barr virus (EBV); human herpesvirus type-8 (HHV-8); intravascular lymphoma; primary effusion lymphoma; skin biopsy

\begin{abstract}
Primary effusion lymphoma (PEL) was initially described in patients with human immunodeficiency virus (HIV)/acquired immune deficiency syndrome (AIDS) ${ }^{1}$ who developed body cavity effusions containing pleomorphic malignant cells. The neoplastic cells in PEL typically demonstrate an immunoblastic, plasmablastic or anaplastic morphology ${ }^{2}$ and lack most B- and T-cell markers of differentiation, although many show clonal immunoglobulin rearrangements consistent with a B-cell origin. Characteristically, the malignant cells are co-infected with Epstein-Barr virus (EBV) and human herpesvirus-8 (HHV-8)/Kaposi sarcoma-associated herpesvirus. ${ }^{3}$ PEL has also been reported in other
\end{abstract}

(C) 2014 John Wiley \& Sons A/S. Published by John Wiley \& Sons Ltd

Janis M. Taube, MD Division of Dermatopathology Blalock 907, 600 N. Wolfe St, Baltimore, MD 21287 Tel: +410 9553484 Fax: +4109552445 jtaube1@jhmi.edu. 
immunosuppressed individuals including the elderly and patients who have had solid organ transplants. $^{4,5}$

The potential for a varied clinical presentation of PEL is now well established. While cavitary effusions are typical of this entity, ${ }^{3,6}$ solid tumors composed of cells with the morphology and immunophenotype of PEL have also been observed. ${ }^{7-11}$ These mass lesions demonstrate an aggressive course and poor response to therapy as is also seen with neoplastic effusions. $2,7,9,11$ The solid tumors have been designated 'extracavitary PEL'11 and are only rarely associated with the subsequent development of effusions. ${ }^{7,11}$ An unusual entirely intravascular form of PEL without an associated mass lesion or effusion was also recently described. ${ }^{12}$

Intravascular lymphomas are most commonly diffuse large B-cell lymphomas; however, intravascular forms of other major subtypes of lymphoma including anaplastic large cell lymphoma (ALCL) have also been reported. ${ }^{13,14}$ The clinical diagnosis of intravascular lymphoma can be challenging owing to the varied symptoms at presentation, which range from neurologic symptoms to multi-system organ failure. ${ }^{2}$ Intravascular lymphomas often lack bone marrow or lymph node involvement, and skin biopsies are one of the most effective tools for identifying the intravascular lesions. ${ }^{15,16}$

In this report, we describe a patient who presented with skin lesions clinically favored to represent Kaposi sarcoma (KS) in the context of newly diagnosed HIV/AIDS. Histopathologic study demonstrated that the skin lesions represented an intravascular lymphoma with a PEL-like immunophenotype, and the patient subsequently developed a pleural effusion.

\section{Report of a patient}

\section{Clinical findings}

A 53-year-old man with a history of hypertension presented with fatigue, unintentional weight loss (40 lbs over 6 months), fever and vague neurologic complaints including lightheadedness and lower extremity weakness. He had a CD4 count in the 50s (normal range: 458-1344 cells/cu mm) and was diagnosed with HIV and AIDS-defining conditions including herpes simplex virus and cytomegalovirus esophagitis, as well as Pneumocystis jirovecii. There was no evidence of a pleural effusion on imaging at this time. Physical examination also revealed two dark macules on his right calf (medial and lateral) that were clinically concerning for KS. Antiviral and antimicrobial agents were initiated, and a biopsy of one of the calf lesions was performed.

Approximately 2 weeks later, the patient developed progressively worsening shortness of breath, a non-productive cough and tachycardia with continued fevers, weakness and new onset urinary retention. Imaging of the chest and abdomen at this time revealed large bilateral pleural effusions (Fig. 1) and hepatosplenomegaly. He had developed 2+ pitting edema in the left upper extremity with evidence of deep vein thrombosis in the left axillary and subclavian veins. A repeat skin exam did not note any change in the appearance of the lesions. The patient also developed new cytopenias, thought to be secondary to initiation of 
highly aggressive anti-retroviral therapy (HAART). Specifically, prior to beginning the drug regimen, he was slightly anemic; however, 2 weeks into therapy he developed pancytopenia.

The skin biopsy from the right calf revealed intravascular lymphoma with EBV and HHV-8 co-infection of the neoplastic cells (Figs. 2 and 3, Table 1). Similar cells were subsequently identified within the pleural effusion. Shortly after the diagnosis of PEL, the patient developed an acute abdomen with bowel ischemia, perforation and peritonitis requiring a sigmoid colon resection, and vessels within the bowel wall were also found to contain neoplastic cells (Table 1). The patient's clinical and mental status continued to decline until he was only minimally responsive without sedation. Per family wishes, he was transitioned to hospice care and died approximately 5 weeks after the initial skin biopsy. An autopsy was not performed, and death was attributed to complications from AIDS.

\section{Histopathologic findings}

The skin biopsy specimen from the right calf was received for review by our consultation service. Conventional microscopic sections demonstrated two sections of skin with minimal perivascular lymphocytic inflammation. The deep reticular vascular spaces, particularly those centered around adnexal structures, contained large atypical cells with round or irregular nuclei, moderately condensed chromatin, prominent nucleoli and a moderate amount of eosinophilic cytoplasm (Fig. 2). The vessels of the superficial vascular plexus were largely spared. In some of the atypical cells, nuclei were eccentrically placed and demonstrated a perinuclear hof. The neoplastic cells were confined to the vascular spaces, as highlighted by a CD31 immunostain.

The atypical cells were positive for MUM-1 but were negative for CD138, CD20 and CD3 (Fig. 3). A subset of the atypical cells also expressed CD31. Ki-67 immunostaining demonstrated a very high proliferation index within the atypical cells. In situ hybridization for EBV (Epstein-Barr virus-encoded RNA 1 (EBER 1) was detected using the 760-1209 DNP Probe, Ventana, Tuscon, AZ, and used pre-diluted as received) was positive in many of the atypical cells, as was an immunostain for HHV-8 (LANA-1, Leica Systems, Bannock Burn, IL, NCL-HHV8 at a standard dilution of 1:50). CD3 highlighted scattered periadnexal small, reactive T cells, and CD138 stained squamous epithelium and adnexal structures, as anticipated.

The original skin biopsy was exhausted during the initial work-up. Accordingly, additional characterization of the neoplastic cells was performed on the bowel resection specimen, since similar atypical cells were present within the intravascular spaces of an ischemic segment of large bowel. The tumor cells expressed CD38 and CD79a and showed weak expression of epithelial membrane antigen (EMA) but were negative for Pax5, CD19, CD30, anaplastic lymphoma kinase (ALK), CD56 and T-cell lineage markers (Table 1).

\section{Discussion}

Both PEL and intravascular lymphomas are relatively rare hematopoietic neoplasms with varied clinical and microscopic manifestations, which can make the diagnosis challenging. The range of lymphomas that may present as intravascular lesions is shown in Table 2. The 
histopathologic diagnosis of PEL can be particularly difficult, in part due to the unusual immunophenotype. The cells of PEL characteristically lack expression of some or all B-cell lineage markers such as CD20, CD19 and Pax5, 2,6,9,12 yet express one or more markers that are associated with terminal B-cell differentiation including CD38, CD138 and/or MUM-1.2,9,12,17 Expression of the pan-B cell and plasma cell marker, CD79a, is not uncommon $^{11}$ and was reported in $23 \%$ of cases in one large study of extracavitary PEL lesions. ${ }^{9}$ The morphology, immunophenotype and EBV positivity of the neoplastic cells in PEL may suggest plasmablastic lymphoma, but, unlike PEL, plasmablastic lymphoma is HHV8-negative. PEL can express CD30 9,18 and may also show aberrant expression of Tcell markers CD3, CD4 and CD7, ${ }^{2,5,8,12}$ which can raise the possibility of ALCL or other Tcell lymphomas; however, T-cell lymphomas lack expression of HHV-8. ${ }^{13,14,19}$ In this case, the neoplastic cells were negative for both CD30 and T-cell markers.

The morphologic findings in the present case initially suggested an intravascular large B-cell lymphoma, but the lack of CD20 was unusual, and more detailed characterization demonstrated HHV-8 and EBV co-infection, allowing recognition of this neoplasm as extracavitary PEL. The expression of platelet endothelial cell adhesion molecule-1 (CD31) on the neo-plastic cells in this case was particularly notable given the clinical suspicion for $\mathrm{KS}$; however, while the neoplastic cells expressed both CD31 and HHV-8, the pathologic features were not those of KS. Because CD31 is also expressed in plasma cell neoplasms, ${ }^{20-22}$ we interpret reactivity in this case as a reflection of terminal B-cell differentiation, rather than aberrant expression of a vascular antigen. The neoplastic cells also expressed other markers of terminal B-cell differentiation ${ }^{23}$ including CD38, MUM-1 and EMA, which have also commonly been associated with cavitary and extracavitary PEL. ${ }^{6,11,24}$ CD138, while first thought to be a key feature of PEL, ${ }^{11,24}$ has since been shown to be expressed in only $38 \%$ of classic PEL cases, and $70 \%$ of extracavitary PEL cases. ${ }^{9}$ Its expression was lacking in both the current case and a previously reported case of entirely intravascular PEL. ${ }^{12}$

While singular cases of PEL presenting as a mass lesion in the skin have been described, ${ }^{11}$ to our knowledge this is the first reported case of intravascular PEL presenting with a clinically apparent skin lesion. The skin lesions of intravascular lymphoma can display considerable variability in appearance. Roglin and Boer summarized the skin findings of 224 cases of intravascular lymphomas from 97 previous reports ${ }^{25}$ and found that 90 patients (40\%) had skin lesions at initial presentation with the most commonly affected sites being the thigh, leg, trunk, arm and buttock. The majority of these lesions were described as nodules or plaques (49\%) followed by macules $(22 \%)$, which varied in color from red to blue, brown and gray. Telangectasia was not uncommon ( $20 \%$ of cases), and a smaller proportion of lesions were accompanied by extremity edema and/or pain. ${ }^{25}$ Of note, disparate appearing lesions may also be present in the same patient. For example, in one case report of an 84-year-old woman with intravascular large B-cell lymphoma, a senile angioma-like waxy red papule was noted on her abdomen while purple to brownish patches were present on her lower extremities, ${ }^{26}$ but histopathologic analysis demonstrated intravascular lymphoma in both specimens. Overall, skin manifestations of intravascular lymphoma most often mimic inflammatory disorders and vasculitides, ${ }^{25}$ although this case 
demonstrates that intravascular lymphomas may also mimic other neoplastic processes such as KS.

Recently, we described a case of an entirely intravascular form of extracavitary PEL in which the patient did not go on to develop an associated effusion or mass lesion. ${ }^{12}$ In the entirely intravascular case of extracavitary PEL, grossly identifiable skin lesions were absent, and the neoplastic cells only involved the small to medium sized vessels in the subcutaneous fat, ${ }^{12}$ which is the predominant pattern previously reported for intravascular lymphomas. ${ }^{16,27,28}$ Notably, the current case demonstrated neo-plastic cells within the deep reticular dermal vessels. Subcutaneous tissue was not available for evaluation owing to the superficial nature of the biopsy. In further comparison to the original report of an entirely intravascular form of extracavitary PEL, the original case demonstrated prominent thrombosis that entrapped and obscured the tumor cells, but this feature was not present in the area biopsied in the current case. Interestingly, the current patient did go on to develop upper extremity deep vein thrombosis; however, material was not available to determine whether this was directly related to the neoplastic cells.

In keeping with these two recently described cases of intravascular PEL, other studies have suggested that the extent of extracavitary presentation of the disease may be underestimated. In one series, 9 of 29 patients with PEL who presented with a classic cavitary lesion also had lymphoma in solid tissues including the pericardium, lymph nodes, gastrointestinal tract and skin. ${ }^{11}$ In half of the cases, the solid lesions preceded the development of positive effusions by a period of weeks to months, similar to the current case. In an additional eight cases in this series, only a solid extracavitary component was identified, and the patients never went on to develop a positive effusion. A second group of investigators aimed to identify previously unrecognized presentations of extracavitary PEL by studying all non-Hodgkin lymphomas (NHL) arising in HIV patients at a single large referral center in the Netherlands from 1988 to 2003. They found that presentation of PEL as an extracavitary mass lesion was actually much more common than presentation in a body cavity or effusion in the population studied. ${ }^{7}$ Furthermore, in this study, most cases of extracavitary PEL presenting as a solid mass lesion were not followed by subsequent development of a malignant effusion.

In summary, this case demonstrates an unusual intravascular presentation of PEL with associated skin lesions and emphasizes the importance of skin biopsies in the diagnosis of intravascular lymphomas. Our findings, as well as those of other groups, suggest that the extracavitary presentation of PEL may be less rare than previously believed. In addition, this case supports recognition of an intravascular presentation for this entity. ${ }^{7,11,12}$ Finally, this case highlights the utility of skin biopsies in immunosuppressed individuals, as these patients are more likely to exhibit rare or unusual presentations of disease.

\section{References}

1. Knowles DM, Inghirami G, Ubriaco A, Dalla-Favera R. Molecular genetic analysis of three AIDSassociated neoplasms of uncertain lineage demonstrates their B-cell derivation and the possible patho-genetic role of the Epstein-Barr virus. Blood. 1989; 73:792. [PubMed: 2537119]

2. Swerdlow, SH.; Campo, E.; Harris, NL., et al. WHO Classification of Tumours of Haematopoietic and Lymphoid Tissues. 4th ed.. World Health Organization Press; Geneva, Switzerland: 2008. 
3. Cesarman E, Chang Y, Moore PS, Said JW, Knowles DM. Kaposi's sarcoma-associated herpesvirus-like DNA sequences in AIDS-related body-cavity-based lymphomas. N Engl J Med. 1995; 332:1186. [PubMed: 7700311]

4. Boulanger E, Afonso PV, Yahiaoui Y, Adle-Biassette H, Gabarre J, Agbalika F. Human herpesvirus-8 (HHV-8)-associated primary effusion lymphoma in two renal transplant recipients receiving rapamycin. Am J Transplant. 2008; 8:707. [PubMed: 18261181]

5. Boulanger E, Hermine O, Fermand J-P, et al. Human herpesvirus 8 (HHV-8)-associated peritoneal primary effusion lymphoma (PEL) in two HIV-negative elderly patients. Am J Hematol. 2004; 76:88. [PubMed: 15114607]

6. Nador RG, Cesarman E, Chadburn A, et al. Primary effusion lymphoma: a distinct clinicopathologic entity associated with the Kaposi's sarcoma-associated herpes virus. Blood. 1996; 88:645. [PubMed: 8695812]

7. Deloose STP, Smit LA, Pals FT, Kersten MJ, van Noesel CJ, Pals ST. High incidence of Kaposi sarcoma-associated herpesvirus infection in HIV-related solid immunoblastic/plasmablastic diffuse large B-cell lymphoma. Leukemia. 2005; 19:851. [PubMed: 15744337]

8. Dong HY, Wang W, Uldrick TS, Gangi M. Human herpesvirus 8- and Epstein-Barr virus-associated solitary B cell lymphoma with a T cell immunophenotype. Leuk Lymphoma. 2013; 54:1560. [PubMed: 23228024]

9. Pan Z-G, Zhang Q-Y, Lu Z-BJ, et al. Extra-cavitary KSHV-associated large B-Cell lymphoma: a distinct entity or a subtype of primary effusion lymphoma? Study of 9 cases and review of an additional 43 cases. Am J Surg Pathol. 2012; 36:1129. [PubMed: 22790853]

10. Carbone A, Volpi CC, Caccia D, et al. Extracavitary KSHV-positive solid lymphoma: a large Bcell lymphoma within the spectrum of primary effusion lymphoma. Am J Surg Pathol. 2013; 37:1460. DOI: 10.1097/PAS.0b013e31829caada. [PubMed: 24076781]

11. Chadburn A, Hyjek E, Mathew S, Cesarman E, Said J, Knowles DM. KSHV-positive solid lymphomas represent an extra-cavitary variant of primary effusion lymphoma. Am J Surg Pathol. 2004; 28:1401. [PubMed: 15489644]

12. Crane GM, Ambinder RF, Shirley CM, et al. HHV-8-positive and EBV-positive intravascular lymphoma: an unusual presentation of extracavitary primary effusion lymphoma. Am J Surg Pathol. 2014; 38:426. [PubMed: 24525514]

13. Rieger KE, Polidore T, Warnke R, Kim J. ALK-negative systemic intravascular anaplastic large cell lymphoma presenting in the skin. J Cutan Pathol. 2011; 38:216. [PubMed: 20236372]

14. Metcalf RA, Bashey S, Wysong A, Kim J, Kim YH, Gratzinger D. Intravascular ALK-negative anaplastic large cell lymphoma with localized cutaneous involvement and an indolent clinical course: toward recognition of a distinct clinicopathologic entity. Am J Surg Pathol. 2013; 37:617. [PubMed: 23480896]

15. Le EN, Gerstenblith MR, Gelber AC, Kim J, Kim YH, Gratzinger D. The use of blind skin biopsy in the diagnosis of intravascular B-cell lymphoma. J Am Acad Dermatol. 2008; 59:148. [PubMed: 18406005]

16. Matsue K, Asada N, Odawara J, et al. Random skin biopsy and bone marrow biopsy for diagnosis of intravascular large B cell lymphoma. Ann Hematol. 2011; 90:417. [PubMed: 20957365]

17. Wang H-Y, Fuda FS, Chen W, Karandikar NJ. Notch1 in primary effusion lymphoma: a clinicopathological study. Mod Pathol. 2010; 23:773. DOI: 10.1038/modpathol.2010.67. [PubMed: 20348880]

18. Bhatt S, Ashlock BM, Natkunam Y, et al. CD30 targeting with brentuximab vedotin: a novel therapeutic approach to primary effusion lymphoma. Blood. 2013; 122:1233. [PubMed: 23838350]

19. Deetz CO, Gilbertson KG, Anadkat MJ, Dehner LP, Lu D. A rare case of intravascular large T-cell lymphoma with an unusual T helper phenotype. Am J Dermatopathol. 2011; 33:e99. [PubMed: 22024573]

20. Medina F. The heterogeneity shown by human plasma cells from tonsil, blood, and bone marrow reveals graded stages of increasing maturity, but local profiles of adhesion molecule expression. Blood. 2002; 99:2154. [PubMed: 11877292] 
21. Govender D, Harilal P, Dada M, Chetty R. CD31 (JC70) expression in plasma cells: an immunohistochemical analysis of reactive and neoplastic plasma cells. J Clin Pathol. 1997; 50:490. [PubMed: 9378815]

22. Plocharczyk E, Wakely PE. CD31 expression in plasmacytic/plasmablastic lesions. Ann Diagn Pathol. 2013; 17:498. [PubMed: 24074836]

23. Colomo L, Loong F, Rives S, et al. Diffuse large B-cell lymphomas with plasmablastic differentiation represent a heterogeneous group of disease entities. Am J Surg Pathol. 2004; 28:736. [PubMed: 15166665]

24. Carbone A, Gloghini A, Vaccher E, et al. Kaposi's sarcoma-associated herpesvirus/human herpesvirus type 8-positive solid lymphomas: a tissue-based variant of primary effusion lymphoma. J Mol Diagn. 2005; 7:17. [PubMed: 15681470]

25. Röglin J, Böer A. Skin manifestations of intravascular lymphoma mimic inflamma-tory diseases of the skin. Br J Dermatol. 2007; 157:16. [PubMed: 17506787]

26. Nakajima S, Ohshima K, Kyogoku M, Miyachi Y, Kabashima K. A case of intravascular large Bcell lymphoma with atypical clinical manifestations and analysis of CXCL12 and CXCR4 expression. Arch Dermatol. 2010; 146:686. [PubMed: 20566945]

27. Deschamps L, Signate A, Delaunay C, et al. A blind skin biopsy diagnosing an intravascular large B-cell lymphoma. Eur J Dermatol. 2010; 21:114. [PubMed: 21233067]

28. Perniciaro C, Winkelmann RK, Daoud MS, Su WP. Malignant angioendotheliomatosis is an angiotropic intravascular lymphoma. Immunohistochemical, ultrastructural, and molecular genetics studies. Am J Dermatopathol. 1995; 17:242. [PubMed: 8599432]

29. Murase T, Yamaguchi M, Suzuki R, et al. Intravascular large B-cell lymphoma (IVLBCL): a clinicopathologic study of 96 cases with special reference to the immunophenotypic heterogeneity of CD5. Blood. 2007; 109:478. [PubMed: 16985183]

30. Ferreri AJM, Campo E, Seymour JF, et al. Intravascular lymphoma: clinical presentation, natural history, management and prognostic factors in a series of 38 cases, with special emphasis on the "cutaneous variant". Br J Haematol. 2004; 127:173. [PubMed: 15461623]

31. Isimbaldi G, Corral L, Songia S, Valente MG, De Bianchi S, Biondi A. An unusual presentation of a case of T cell angiotropic (intravascular) lymphoma. Leukemia. 2000; 14:2321. [PubMed: 11187923]

32. Cerroni L, Massone C, Kutzner H, Mentzel T, Umbert P, Kerl H. Intravascular large T-cell or NKcell lymphoma: a rare variant of intravascular large cell lymphoma with frequent cytotoxic phenotype and association with Epstein-Barr virus infection. Am J Surg Pathol. 2008; 32:891. [PubMed: 18425045]

33. Wu H, Said JW, Ames ED, et al. First reported cases of intravascular large cell lymphoma of the NK cell type: clinical, histologic, immunophenotypic, and molecular features. Am J Clin Pathol. 2005; 123:603. [PubMed: 15743739]

34. Riveiro-Falkenbach E, Fernández-Figueras MT, Rodríguez-Peralto JL. Benign atypical intravascular CD30(+) T-cell proliferation: a reactive condition mimicking intravascular lymphoma. Am J Dermatopathol. 2013; 35:143. [PubMed: 23542715] 


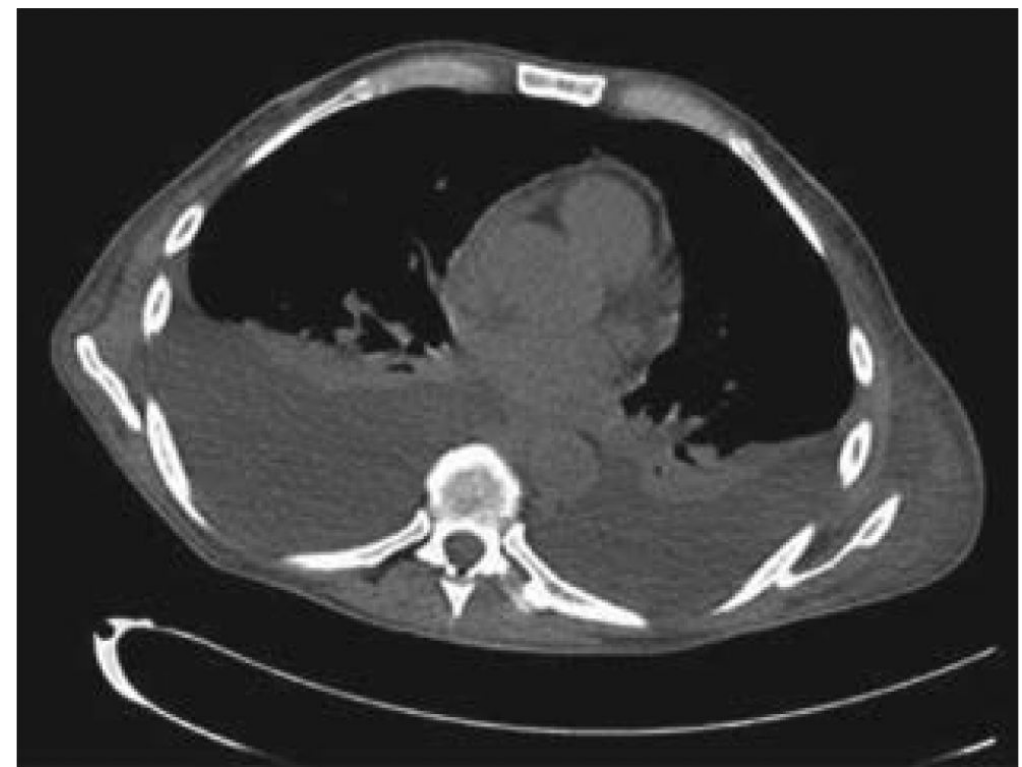

Fig. 1.

Bilateral malignant pleural effusions. A computed tomography image demonstrates large bilateral pleural effusions, which developed approximately 2 weeks after the initial skin biopsy. Cytology studies on the pleural fluid (not shown) demonstrated neoplastic cells consistent with primary effusion lymphoma. 

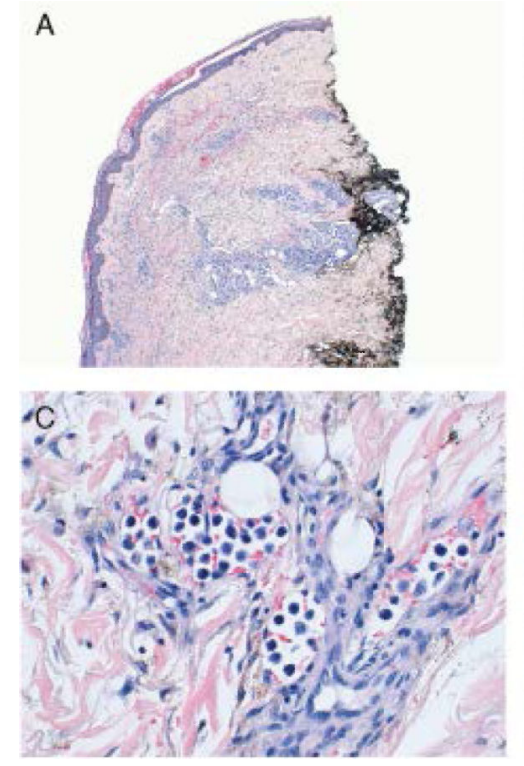
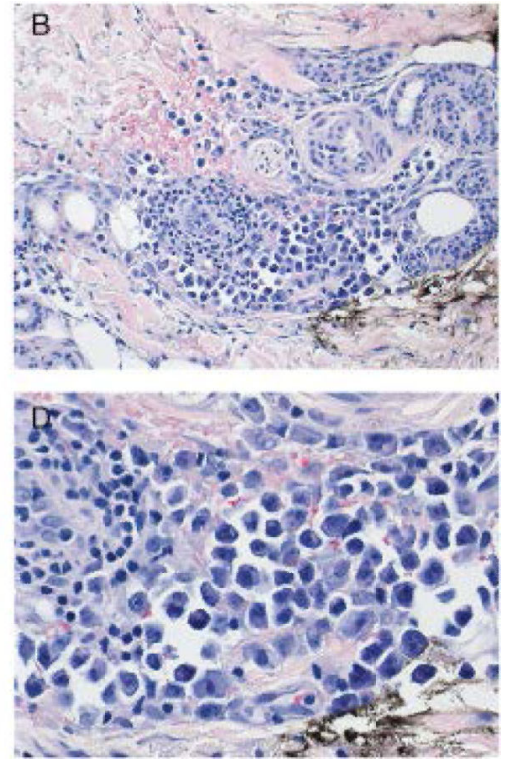

Fig. 2.

An intravascular presentation of primary effusion lymphoma (PEL) in the dermal vessels of a 53-year-old man with acquired immune deficiency syndrome (AIDS). The skin biopsy (A, hematoxylin/eosin stain, $\times 20$ original magnification) demonstrated an atypical cell population within vascular spaces in the dermis, including vessels adjacent to adnexal structures (B and C, hematoxylin/eosin stain, $\times 100$ and $\times 160$ original magnification, respectively). The neoplastic cells had a plasmablastic appearance with eosinophilic cytoplasm, perinuclear hofs, eccentric nuclei, moderately condensed chromatin and prominent central nucleoli (D, hematoxylin/eosin stain, $\times 254$ original magnification). 

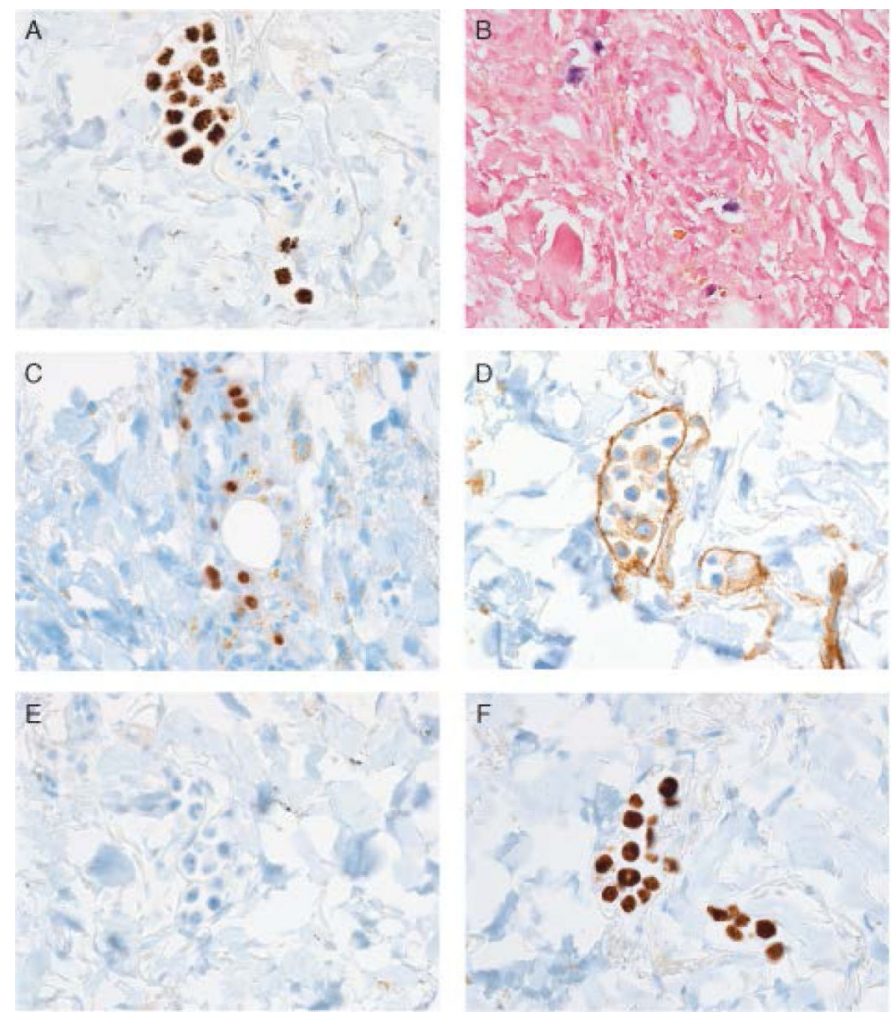

Fig. 3.

The atypical cells co-express plasma cells markers and demonstrate co-infection with Epstein-Barr virus (EBV) and human herpesvirus-8 (HHV-8), consistent with primary effusion lymphoma (PEL). The atypical cells were positive for HHV-8 (A, by immunohistochemistry [IHC] for LANA-1), EBV (B, by in situ hybridization for EBER) and MUM-1 (C, by IHC). IHC for CD31 highlighted vascular endothelial cells as well as a fraction of the intraluminal neoplastic cells (D). The atypical cells were negative for CD20 (E), and nearly all were Ki-67-positive (F). ×254 original magnification, all images. 


\section{Table 1}

Summary of immunohistochemical and in situ hybridization studies

\begin{tabular}{|c|c|}
\hline Marker & Expression \\
\hline$\overline{\mathrm{CD} 45}$ & Weak subset positive \\
\hline \multicolumn{2}{|c|}{ B-cell lineage markers } \\
\hline $\mathrm{CD} 20$ & Negative \\
\hline CD19 & Negative $^{*}$ \\
\hline CD179a & Positive ${ }^{*}$ \\
\hline Pax 5 & Negative $^{*}$ \\
\hline \multicolumn{2}{|c|}{ Plasma cell-associated markers } \\
\hline MUM-1 & Positive \\
\hline $\mathrm{CD} 31$ & Positive \\
\hline CD138 & Negative \\
\hline $\mathrm{CD} 38$ & Positive ${ }^{*}$ \\
\hline Kappa/lambda & Lambda predominant \\
\hline \multicolumn{2}{|l|}{ T-cell markers } \\
\hline $\mathrm{CD} 3$ & Negative \\
\hline $\mathrm{CD} 4$ & Negative $^{*}$ \\
\hline CD5 & Negative $^{*}$ \\
\hline $\mathrm{CD} 7$ & Negative ${ }^{*}$ \\
\hline $\mathrm{CD} 8$ & Negative $^{*}$ \\
\hline HHV-8 & Positive \\
\hline EBER (EBV) & Positive \\
\hline \multicolumn{2}{|l|}{ Other } \\
\hline CD30 & Negative $^{*}$ \\
\hline EMA & Weakly positive ${ }^{*}$ \\
\hline ALK & Negative ${ }^{*}$ \\
\hline CD56 & Negative $^{*}$ \\
\hline Ki-67 & Approximately $100 \%$ \\
\hline
\end{tabular}

EBV, Epstein-Barr virus; HHV, human herpesvirus-8.

* Stains were performed only on the bowel resection specimen to further immunophenotype the infiltrate, as the skin biopsy material was limited. 
Table 2

Intravascular lymphomas associated with skin and subcutaneous tissue involvement

\begin{tabular}{|c|c|c|c|}
\hline & Description & Clinical features & Cell phenotype \\
\hline IVLBCL & $\begin{array}{l}\text { Large atypical } \\
\text { mononuclear cells with } \\
\text { prominent nucleoli are } \\
\text { present in the lumina of } \\
\text { vessels, particularly small } \\
\text { or intermediate sized } \\
\text { vessels. Fibrin thrombi, } \\
\text { hemorrhage and necrosis } \\
\text { can be seen }{ }^{2}\end{array}$ & $\begin{array}{l}\text { Widely disseminated in } \\
\text { extranodal sites. B symptoms } \\
\text { common. Poor prognosis. } \\
\text { Western variant: predominantly } \\
\text { neurological or cutaneous } \\
\text { presentation. } \\
\text { Asian variant: multiorgan } \\
\text { failure, hepatosplenomegaly } \\
\text { and hematophagocytic } \\
\text { syndrome }^{2}\end{array}$ & $\begin{array}{l}\text { B-cell antigens (CD20, CD19, } \\
\text { Pax-5), CD5 and CD10 may be } \\
\text { expressed; CD10 negative cases are } \\
\text { usually MUM1 positive } \\
2,29\end{array}$ \\
\hline Cutaneous variant of IVLBCL & $\begin{array}{l}\text { As above, but with } \\
\text { limitation to the skin }{ }^{2}\end{array}$ & $\begin{array}{l}\text { Better prognosis than } \\
\text { disseminated IVLBCL. } \\
\text { Described predominantly in } \\
\text { Western females }\end{array}$ & As above \\
\hline T-cell intravascular lymphoma & $\begin{array}{l}\text { Large atypical } \\
\text { mononuclear cells with } \\
\text { prominent nucleoli are } \\
\text { present in the lumina of } \\
\text { vessels, particularly } \\
\text { capillaries, small vessels } \\
\text { and lymphatics } 19,31\end{array}$ & $\begin{array}{l}\text { Rare. } \\
\text { Recurrent fevers, arthralgias, } \\
\text { cutaneous rash, multiorgan } \\
\text { failure and rapid disease } \\
\text { progression }^{31}\end{array}$ & $\begin{array}{l}\text { Most are positive for CD } 45, \text { CD3, } \\
\text { TIA-1 and EBV; CD4 and CD } 30 \\
\text { expression have been reported }\end{array}$ \\
\hline $\begin{array}{l}\text { Intravascular large NK/T-cell } \\
\text { lymphoma }\end{array}$ & $\begin{array}{l}\text { Proliferation of medium to } \\
\text { large atypical lymphocytes } \\
\text { with pleomorphic nuclei } \\
\text { within lumina of dilated } \\
\text { vessels } 32\end{array}$ & $\begin{array}{l}\text { Rare. } \\
\text { Skin involvement is typical and } \\
\text { may be only site of } \\
\text { involvement. Rapidly } \\
\text { progressive course }^{32}\end{array}$ & $\begin{array}{l}\text { May express CD3, CD2, CD7, CD8, } \\
\text { CD56, or cytotoxic antigens } \\
\text { Often EBV-positive. CD5 and } \\
\text { betaF1 antibody negative }{ }^{32,33}\end{array}$ \\
\hline Intravascular ALK-negative ALCL & $\begin{array}{l}\text { Large, cohesive, } \\
\text { pleomorphic cells } \\
\text { associated with necrosis } \\
\text { and localized to the } \\
\text { lymphatics } \\
\text { lym,14 }^{13}\end{array}$ & $\begin{array}{l}\text { Rare. } \\
\text { Red to violaceous plaques on } \\
\text { skin. May represent a form of } \\
\text { primary cutaneous ALCL and } \\
\text { have an indolent course }\end{array}$ & $\begin{array}{l}\mathrm{CD} 30+\text {, usually } \mathrm{CD} 3+\text { and negative } \\
\text { for } \mathrm{EBV}^{14}\end{array}$ \\
\hline PEL and extra-cavitary PEL & $\begin{array}{l}\text { Large atypical cells with } \\
\text { round to oval nuclei, } \\
\text { prominent nucleoli and } \\
\text { moderate eosinophilic } \\
\text { cytoplasm. Classic PEL } \\
\text { may have plasmablastic, } \\
\text { immunoblastic or } \\
\text { anaplastic morphology }{ }^{2}\end{array}$ & $\begin{array}{l}\text { Classic presentation as effusion } \\
\text { or cavitary lesion, also reported } \\
\text { as a mass. Reported primary } \\
\text { presentation as an intravascular } \\
\text { lesion in the hypodermic } \\
\text { vessels, }^{12} \text { and as an } \\
\text { intravascular lesion with dermal } \\
\text { involvement preceding } \\
\text { development of a positive } \\
\text { effusion (this report). Seen in } \\
\text { the setting of HIV/AIDS or } \\
\text { other immunosuppression }^{2}\end{array}$ & $\begin{array}{l}\text { Universally HHV- } 8 \text { positive and } \\
\text { usually EBV-positive. } \\
\text { Often express MUM-1 or plasma } \\
\text { cell markers. Usually express CD } 45 \text {, } \\
\text { but lack expression of typical B-cell } \\
\text { markers, but may express CD30, } \\
\text { CD38, CD138 and/or EMA. May } \\
\text { show aberrant expression of T-cell } \\
\text { antigens }\end{array}$ \\
\hline $\begin{array}{l}\text { CD30+ reactive lymphoid } \\
\text { proliferation }\end{array}$ & $\begin{array}{l}\text { Atypical intravascular T- } \\
\text { cell proliferation with } \\
\text { diffuse, mixed } \\
\text { inflammatory infiltrate }{ }^{34}\end{array}$ & $\begin{array}{l}\text { Reported cases presented with } \\
\text { ulcerated cutaneous nodules. } \\
\text { Reactive process that does not } \\
\text { progress to systemic disease }{ }^{34}\end{array}$ & $\begin{array}{l}\mathrm{CD} 30+, \mathrm{CD} 3+, \mathrm{CD} 4+, \mathrm{CD} 5+. \\
\text { Negative for CD } 7, \mathrm{CD} 8 \text { and } \mathrm{CD} 20^{34}\end{array}$ \\
\hline
\end{tabular}

AIDS, acquired immune deficiency syndrome; EBV, Epstein-Barr virus; HIV, human immunodeficiency virus; NK, natural killer; PEL, primary effusion lymphoma

The two reported cases both had 2 years of clinical follow-up. 